\title{
Response to State Stomata to the Use of Microbes as Potential Biofertilizers in the Rehabilitation of Cocoa Trees Without Logging
}

\author{
Marliana S. Palad ${ }^{1, *}$, Aminah $^{2}$ \\ ${ }^{1}$ Faculty of Agriculture Technology, Universitas Cokroaminoto Makassar, South Sulawesi 90245, Indonesia \\ ${ }^{2}$ Department of Agronomy, Faculty of Agriculture, Universitas Muslim Indonesia, Makassar, South Sulawesi 90231, \\ Indonesia \\ *Corresponding author,Email: lallypalad@yahoo.co.id
}

\begin{abstract}
The aim of this study was to examine the effect of Trichoderma asperellum and Azotobacter chroococcum applications on the rehabilitation of the roots of side-grafted cocoa plants using the inarching grafting method against the state of stomata. The method used in this study was a split-plot design, with two factors, namely the application of Trichoderma asperellum and Azotobacter chroococcum which were repeated three times each and continued by using the Tukey's test. The results showed that the inoculation of Trichoderma asperellum and Azotobacter chroococcum in the rehabilitation of cocoa roots by inarching grafting had a very significant effect on the stomata of the leaves so that it had the potential to extend the life of the cocoa plants with optimal productivity, without logging the relatively old cocoa trees. The best results obtained were the leaf area was $181.30 \mathrm{~cm}^{2}$, the number of stomata was 62.72 pieces/area of view, the stomata density was $3085,19 \mathrm{n} / \mathrm{mm}^{2}$, and the stomata aperture width was $228,07 \mu \mathrm{m}$ in the inoculation of Azotobacter chroococcum bacteria two times application, and Trichoderma asperellum three times of application using the inarching grafting method which is done at the time of the appearance of the flush.
\end{abstract}

Keywords: Azotobacter chroococcum, Cocoa rehabilitation, Stomata, Trichoderma asperellum.

\section{INTRODUCTION}

Leaves are an important plant organ because they are the main place for photosynthesis, transpiration, and as a means of respiration. The processes of photosynthesis, transpiration, and respiration in leaves are closely related to leaf stomata. Stomata are the most important part of gas exchange (oxygen and carbon dioxide) in plants. Stomata are a modification of the epidermis, usually in the abaxial part of the leaves [1]. The structure of the stomata affects the workings or effectiveness of the stomata during the photosynthesis process. The capacity and rate of photosynthesis increase in line with the increase in the conductance of the stomata, which is significant with the density of the stomata and the decrease in the size of the stomata [2]. Stomata density is known to affect the amount of carbon dioxide fixed by plants [3], where carbon dioxide will be used as a raw material for photosynthesis.

The problem faced by farmers in rehabilitating old and productive cocoa trees in Bantaeng Regency is the reluctance of farmers to cut the stems because the stems still produce fruit after a side grafting replanting program. This will have an impact on the growth and development of the cocoa tree, which will decrease productivity as a result of the hampered nutrient distribution. This is due to an imbalance in the supply of nutrients to the leaves due to old cocoa tree roots.

To overcome this problem, it is necessary to conduct an assessment of rehabilitating old cocoa trees without logging by using the inarching grafting method, which utilizes potential microorganisms, which are widely known as biological fertilizers. One of the potential microorganisms is Trichoderma $s p$. In addition to decomposing organisms, Trichoderma species can also function as biological agents and stimulators of plant growth [4]. Another group of microbes is Azotobacter chroococcum which is a species of rhizobacteria known as a dinitrogen-fixing biological agent, diazotroph, which converts dinitrogen to ammonium through electron reduction and dinitrogen gas protonation [5]. This rhizobacterium acts as an enhancing agent. Plant growth through the production of phytohormones (auxins, cytokinins, and gibberellin) is the main substance that can increase and control plant growth [6][7][8]. Based on the foregoing, the inoculation of Trichoderma asperellum and Azotobacter chroococcum 
in the rhizosphere of side-cocoa plants, which will be rehabilitated by inarching grafting method, needs to be studied and examined in terms of its effect on the physiological aspects of the leaves in the form of the stomata quality of the leaves of the cocoa plant, which is a growth parameter that affects cocoa productivity.

\section{MATERIALS AND METHOD}

The research was carried out in a cocoa plantation located in Gantarangkeke village, Bantaeng Regency, South Sulawesi Province, starting in April 2019. the cocoa seeds of six months old were planted under a cocoa tree stand that is around 20 years old, with a spacing of 4 $\mathrm{x} 4 \mathrm{~m}$. Three holes for planting were made with a size of $60 \times 60 \times 60 \mathrm{~cm}$ and $20 \mathrm{~cm}$ from the old cocoa tree.

This study was conducted using Split Plot Design, with two factors and three replications, with treatment as the main plot inoculation asperellum Trichoderma consisted of four levels, i.e., without T.asperellum (T0), inoculation T.Asperellum one application (T1), two application (T2) and three application (A3) each of $4 \mathrm{~g} \mathrm{~L}^{-}$ ${ }^{1}$ for each cocoa seed [9]. The first application is given when applying compost (made from cocoa pod husks, banana stems, and gliricidia leaves) in each planting hole. The second application is when planting cocoa seeds, which were 15 days after the first application, and the third application is intermittent a week later.

As a subplot was the inoculation of Azotobacter chroococcum consisting of three levels, namely without A.chroococcum (A0), inoculation A.chroococcum one application of (A1) and two applications (A2), each as much as $40 \mathrm{ml} \times 10^{8} \mathrm{CFU}$ for each cocoa seed [10]. The first application was carried out at week 3 after planting in about $10 \mathrm{~cm}$ from the tree at a depth of about $5 \mathrm{~cm}$ at 2 adjacent points, and the second application was carried out one month later. Each treatment used 2 trees so that there were 72 experimental trees, and each experimental tree was grafted with 3 cocoa seeds. The results of the observations were carried out by the ANOVA test to determine the best treatment, continued by using the Tukey's Test and regression and correlation analysis.

\section{RESULTS AND DISCUSSION}

The results of statistical analysis showed that inoculation treatment T.asperellum singly significant effect on leaf area and the maximum were achieved at twice of T.asperellum application. The inoculation treatment of A.chroococcum had a significant effect on leaf area, stomatal density, stomata aperture width, and the number of stomata, while the interaction of the two potential microbial inoculation treatments had no significant effect on the observed parameters (Table 1).

From table 1 shows that inoculation T.asperellum (T2) twice yielded the highest leaf area, but not significantly different from the one-time inoculation of T.asperellum. Leaves are the main factor that determines the amount of light that can be absorbed by plants for photosynthesis [11]. The wider the leaves, the more amount of solar radiation that can be absorbed by plants, so that the amount of assimilates produced in the photosynthesis process is greater to support plant growth.

The results showed that inoculating T.asperellum (Picture 1) and A.chroococcum (Figure 2) positively correlated linearly with the development of leaf area, number of stomata, stomatal density, and stomata aperture width. Previous studies on cocoa and other different plants inoculated with T.asperellum singly or in multiple ways with PGPR showed wider leaf area in infected plants T.asperellum such as tomato [12] and cucumber [13].

The development of the number, density, and aperture width of the stomata were positively correlated linearly with leaf area. The wider the leaves, the more the number of stomata, with the regression equation $Y=0.2108 x+20.936$ and positively correlated with the value $(\mathrm{R}=0.90)$, the stomata is closer to the regression equation $\mathrm{Y}=10.486 \mathrm{x}+10419$ with a correlation value $(\mathrm{R}$ $=0.90)$ and the wider the stomata aperture width with the regression equation $\mathrm{Y}=0.5693 \mathrm{x}+115.59$ and positively correlated with the value $(\mathrm{R}=0.83)$ (Figure $3 \mathrm{a})$.

The number of stomata correlated positively linearly with stomata density, leaf stomata, and stomata aperture width. The greater the number of stomata, the greater the stomata density and the stomata aperture width of the cocoa leaves (Figure 3b).

Correlation analysis in Figure $3 \mathrm{~b}$ shows that inoculation T.asperellum and A.chroococcum produced a positive linear correlation between the number of stomata and the stomatal density of $Y=49.757 x+0.2019$ with a correlation value of 1 , and the stomata aperture width of $\mathrm{Y}=2.501 \mathrm{x}+69.564$ with a correlation value of 0.8516 The development of better leaf area in plants inoculated T.asperellum and A.chroococcum were due to improved nutrient availability, especially nitrogen by free $\mathrm{N}$ fixation by A.chroococcum [14] and $\mathrm{P}$ availability by activity A.chroococcum [15], which leads to a higher rate of photosynthesis which further increases the rate of leaf area development and overall plant growth.

\section{DISCUSSION}

Soil inoculation with microbes T.asperellum and A.chroococcum has integrated soil management, and efforts have been made for the effectiveness and efficiency of nutrient use in cultivated crops, including cocoa. Inoculation of A.chroococcum and T.Asperellum singly or double has been reported by some researchers to increase the production of plants that function as biological fertilizers and biological control agents [16] [17]. Nutritional status and assimilates in plants will affect the growth of cocoa plants. Lack of water in the leaf tissue will inhibit the rate of photosynthesis because the turgidity of the stomata guard cells will decrease, which causes the stomata to close. The closure of the stomata on the leaves will reduce the rate of $\mathrm{CO} 2$ uptake at the same time and will ultimately reduce the rate of photosynthesis [18]. 
Table 1. Average data on leaf area, the density of stomata, stomata aperture width, and number of stomata

\begin{tabular}{|c|c|c|c|c|}
\hline Treatment & $\begin{array}{l}\text { Leaf area } \\
\quad\left(\mathrm{cm}^{2}\right)\end{array}$ & $\begin{array}{l}\text { Stomata density } \\
\qquad\left(\mathrm{n} / \mathrm{mm}^{2}\right)\end{array}$ & $\begin{array}{l}\text { stomata } \\
\text { aperture width } \\
(\mu \mathrm{m})\end{array}$ & $\begin{array}{c}\text { Number of } \\
\text { stomata per area } \\
\text { of view }\end{array}$ \\
\hline $\begin{array}{l}\text { Trichoderma.asperellum } \\
\text { T0 } \\
\text { T1 } \\
\text { T2 } \\
\text { T3 }\end{array}$ & $\begin{array}{l}136.93^{\mathrm{a}} \\
154.64^{\mathrm{b}} \\
145.79^{\mathrm{ab}} \\
162.86^{\mathrm{b}}\end{array}$ & $\begin{array}{l}2462.71 \\
2601.40 \\
2576.98 \\
2816.57\end{array}$ & $\begin{array}{l}199.52 \\
195.29 \\
196.30 \\
213.75\end{array}$ & $\begin{array}{l}49.67 \\
52.33 \\
52.00 \\
56.67\end{array}$ \\
\hline Tukey $\alpha$ 12:05 & $14: 21$ & - & - & - \\
\hline $\begin{array}{c}\text { Azotobacter.chroococcum } \\
\text { A0 } \\
\text { A1 } \\
\text { A2 }\end{array}$ & $\begin{array}{l}133.65^{\mathrm{a}} \\
155.57^{\mathrm{b}} \\
160.95^{\mathrm{b}}\end{array}$ & $\begin{array}{l}2374.37^{\mathrm{a}} \\
2652.20^{\mathrm{ab}} \\
2816.69^{\mathrm{b}}\end{array}$ & $\begin{array}{l}185.84^{\mathrm{a}} \\
204.34^{\mathrm{a}} \\
212.71^{\mathrm{b}}\end{array}$ & $\begin{array}{l}48.00^{\mathrm{a}} \\
53.25^{\mathrm{ab}} \\
56.75^{\mathrm{b}}\end{array}$ \\
\hline Tukey $\alpha$ 0:05 & 18.86 & 328.27 & 23.88 & 6.60 \\
\hline $\begin{array}{l}\text { T0A0 } \\
\text { T0A1 } \\
\text { T0A1 } \\
\text { T1A0 } \\
\text { T1A1 } \\
\text { T1A2 } \\
\text { T2A0 } \\
\text { T2A1 } \\
\text { T2A2 } \\
\text { T3A0 } \\
\text { T3A1 } \\
\text { T3A2 }\end{array}$ & $\begin{array}{l}110.09 \\
138.74 \\
161.34 \\
145.09 \\
144.26 \\
161.01 \\
164.39 \\
162.72 \\
156.45 \\
164.17 \\
162.86 \\
181.30\end{array}$ & $\begin{array}{l}2324.95 \\
2449.35 \\
2613.84 \\
2322.19 \\
2700.92 \\
2781.09 \\
2413.41 \\
2530.91 \\
2786.29 \\
2436.91 \\
2927.62 \\
3085.19\end{array}$ & $\begin{array}{l}183.23 \\
207.45 \\
207.89 \\
181.79 \\
199.79 \\
204.27 \\
177.69 \\
197.59 \\
210.59 \\
200.65 \\
212.52 \\
228.07\end{array}$ & $\begin{array}{l}46.72 \\
49.22 \\
52.53 \\
46.67 \\
54.28 \\
55.89 \\
48.50 \\
50.86 \\
56.00 \\
48.97 \\
58.83 \\
62.72\end{array}$ \\
\hline
\end{tabular}

Note: numbers followed by the same letter in the same column mean no significant difference at the Tukey's test of level $5 \%$.
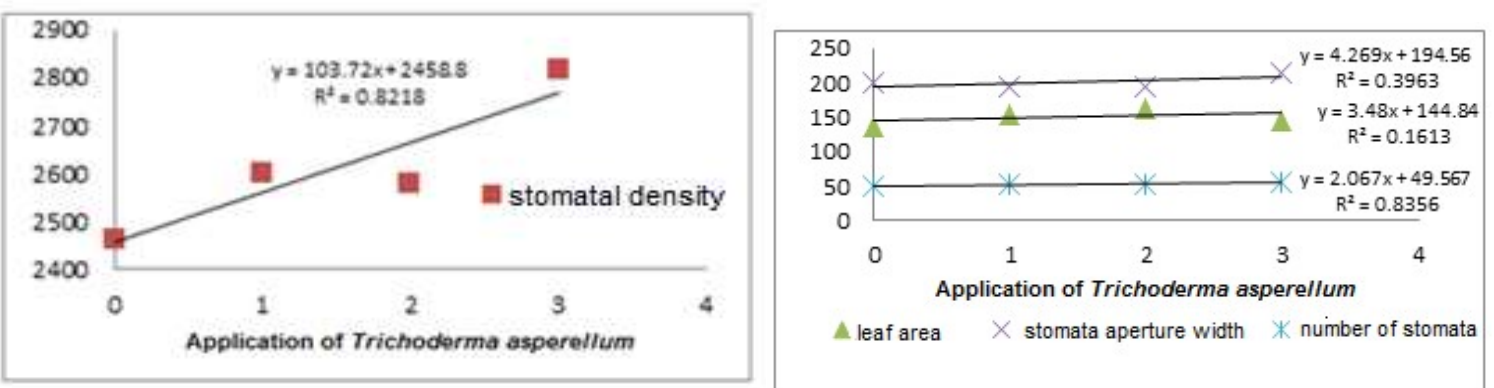

Figure 1 Graph of the relationship between applications Trichoderma asperellum with leaf area, number of stomata, stomata density, stomata aperture width. 

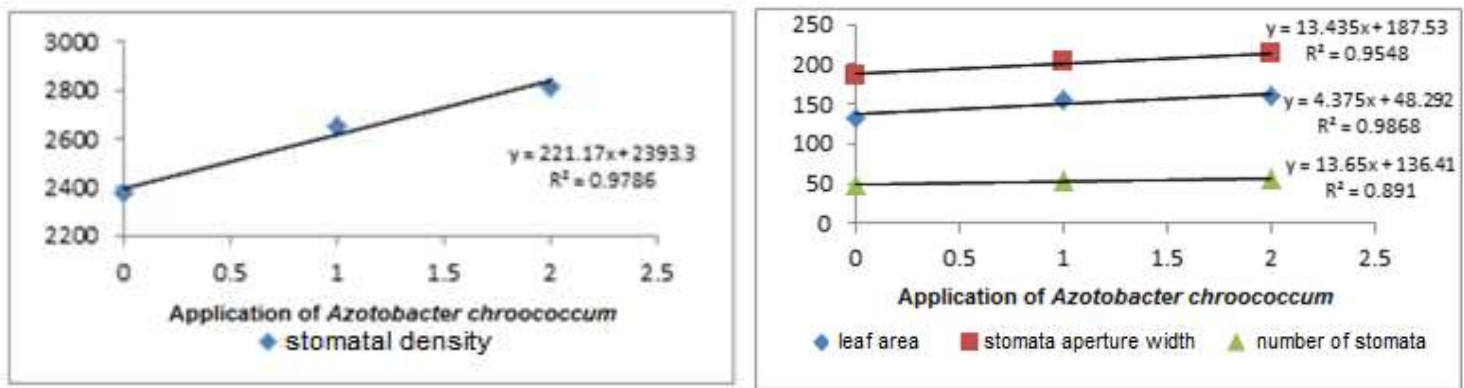

Figure 2 Graph of the relationship between application Azotobacter.chroococcum with leaf area, number of stomata, stomata density, and stomata aperture width.

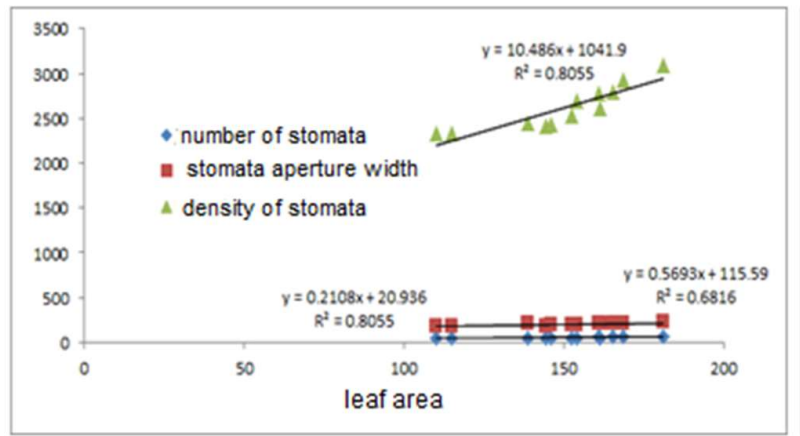

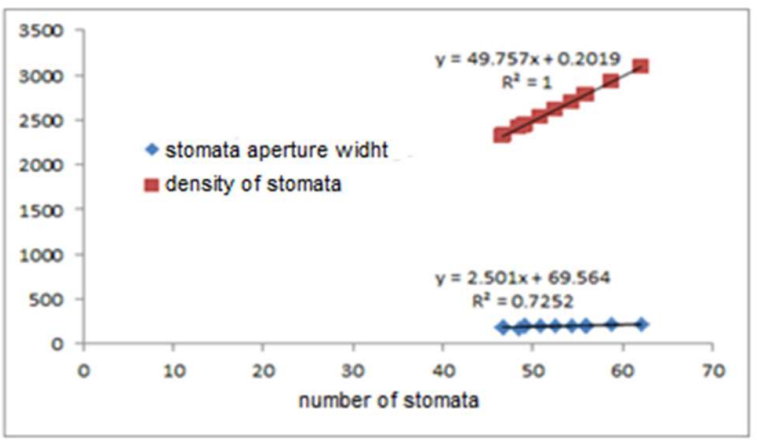

Figure 3 Graph of the relationship between leaf area, number of stomata, stomata density, and stomata aperture width after application Trichoderma asperellum and Azotobacter.chroococcum (a), Graph of the relationship between the number of stomata with the stomata density and stomata aperture width after application Trichoderma asperellum and Azotobacter.chroococcum (b).

The three times treatment application of T.asperellum with a dose of $4 \mathrm{~g} \cdot \mathrm{mL}^{-1}$ showed that the average number of stomata and stomata aperture width was better than other treatments (Table 1). Fungus of T.asperellum serves as additional material to accelerate the weathering process of organic matter from manure, compost of pod husks, and cocoa leaves so that NPK and other nutrients are available to plants. Apart from that, as a biological agent, T.asperellum also functions to loosening soil, prevent soil-borne plant diseases, and improve soil structure and break down the nutrients bound in the soil.

The benefits of this fungus have an impact on the availability of nutrients in the soil. According to [19], plants given the fungus were Trichoderma able to stimulate plant growth by increasing root size and root length so that it can help in nutrient absorption. $\mathrm{N}$ content affects crop production. The more the $\mathrm{N}$ content increases the chlorophyll, protein, and cocoa production. This is closely related to the process of opening and closing the stomata. Opening and closing the stomata is important for the assimilation of $\mathrm{CO} 2$ and also the balance of water in plants. Opening and closing of the stomata depend on changes in the turgor of the stomata guard cells. High turgor causes the stomata to open otherwise, low turgor will cause the stomata to close. The mechanism for opening and closing the stomata mainly depends on the accumulation of $\mathrm{K}^{+}$in the stomata cells and the hydrolysis of starch into sugar [20], so that the stomata state of cocoa leaves is crucial in increasing cocoa productivity.

\section{CONCLUSIONS}

The conclusion from the research results is that rehabilitation of cocoa plants that are relatively old can be done without the need for logging cocoa trees by modifying inarching grafting with an environmentally friendly agricultural system by utilizing the bacteria Azotobacter chroococcum and the fungus Trichoderma asperellum, so that farmers do not need a long time to keep their cocoa plants productive in producing cocoa beans. The best results obtained were the leaf area was $181.30 \mathrm{~cm}^{2}$, the number of stomata was 62.72 pieces/area of view, the stomata density was $3085,19 \mathrm{n} / \mathrm{mm}^{2}$, and the stomata aperture width was $228,07 \mu \mathrm{m}$ in the inoculation of A.chroococcum bacteria two times application, and T.asperellum three times of application using the inarching grafting method which is done at the time of the appearance of the flush. 


\section{ACKNOWLEDGMENT}

The authors would like to thank the Directorate of Research and Community Service, Deputy of Strengthening Research and Development, the Ministry of Technology Research/National Research and Innovation Agency of Indonesia (Grant no.7/E/KPT/2019) for funding this research.

\section{REFERENCES}

[1] M. Durand et al., "Element content and expression of genes of interest in guard cells are connected to spatiotemporal variations in stomatal conductance," Plant Cell and Environment, vol. 43, no. 1, pp. 87-102, 2020, DOI: https://doi.org/10.1111/pce.13644.

[2] J. Wang, W. Lu, Y. Tong, and Q. Yang, "Leaf morphology, photosynthetic performance, chlorophyll fluorescence, stomatal development of lettuce (Lactuca sativa L.) exposed to different ratios of red light to blue light," Frontiers in Plant Science, vol. 7, no. MAR2016, pp. 1-10, 2016,

DOI:

https://doi.org/10.3389/fpls.2016.00250.

[3] J. Dunn et al., "Reduced stomatal density in bread wheat leads to increased water-use efficiency," Journal of Experimental Botany, vol. 70, no. 18, pp. 4737-4747, 2019, DOI: https://doi.org/10.1093/jxb/erz248.

[4] H. Saba, D. Vibhash, M. Manisha, P. Ks, H. Farhan, and A. Tauseef, "Trichoderma - a promising plant growth stimulator and biocontrol agent," Mycosphere, vol. 3, no. 4, pp. 524-531, 2012,

DOI:

https://doi.org/10.5943/mycosphere/3/4/14.

[5] O. Damir, Š. Božidar, and N. Sr, "Cultivation of the bacterium Azotobacter chroococcum for preparation of biofertilizers," vol. 10, no. 16, pp. 3104-3111, 2011, DOI: https://doi.org/10.5897/AJB10.1086.

[6] S. A. Wani, S. Chand, and T. Ali, "Potential Use of Azotobacter chroococcum in Crop Production : An Overview," Current Agriculture Research Journal, vol. 1, no. 1, pp. 35-38, 2013.

[7] C. Srinivasarao and M. Manjunath, "Potential of beneficial bacteria as eco-friendly options for chemical-free alternative agriculture," PlantMicrobe Interactions in Agro-Ecological Perspectives, vol. 2, pp. 473-493, 2017, DOI: https://doi.org/10.1007/978-981-10-65934_19.

[8] A. H. Sodiq, M. R. Setiawati, D. A. Santosa, and D. Widayat, "The potency of bio-organic fertilizer containing local microorganism of
Cibodas village, Lembang-West Java," IOP Conference Series: Earth and Environmental Science, vol. 383, no. 1, 2019, DOI: https://doi.org/10.1088/17551315/383/1/012001.

[9] M. S. Palad, A. Ala, and Nasaruddin, "Effectiveness Trichoderma asperellum on the Growth Cocoa Seeds under the Old Cocoa Trees," Modern Applied Science, vol. 10, no. 11, pp. 176-180, 2016, DOI: https://doi.org/10.5539/mas.v10n11p176.

[10] Nasaruddin and I. Ridwan, "Effectivity of Azotobacter chroococcum and arbuscular mycorrhiza fungi on physiological characteristics and growth of cocoa seedlings," IOP Conference Series: Earth and Environmental Science, vol. 157, no. 1, pp. 0-6, 2018, DOI: https://doi.org/10.1088/17551315/157/1/012014.

[11] A. A. Gitelson, Y. Peng, A. Viña, T. Arkebauer, and J. S. Schepers, "Efficiency of chlorophyll in gross primary productivity: A proof of concept and application in crops," Journal of Plant Physiology, vol. 201, pp. 101-110, 2016, DOI: https://doi.org/10.1016/j.jplph.2016.05.019.

[12] D. V. C. França, K. C. Kupper, M. M. R. Magri, T. M. Gomes, and F. Rossi, "Trichoderma spp. isolates with potential of phosphate solubilization and growth promotion in cherry tomato1," Pesquisa Agropecuária Tropical, vol. 47, no. 4, pp. 360-368, 2017, DOI: https://doi.org/10.1590/1983$40632017 \mathrm{v} 4746447$.

[13] L. I. Mei et al., "The effects of Trichoderma on preventing cucumber fusarium wilt and regulating cucumber physiology," Journal of Integrative Agriculture, vol. 18, no. 3, pp. 607617, 2019, DOI: https://doi.org/10.1016/S2095-3119(18)62057$\mathrm{X}$.

[14] F. Romero-Perdomo et al., "Azotobacter chroococcum as a potentially useful bacterial biofertilizer for cotton (Gossypium hirsutum): Effect in reducing N fertilization," Revista Argentina de Microbiologia, vol. 49, no. 4, pp. 377-383, 2017, DOI: https://doi.org/10.1016/j.ram.2017.04.006.

[15] Gamaruddin, A. Tahir, A. S. Anita, and B. Asri, "The impact of azotobacter chroococcum and liquid organic fertilizer on nutrients nitrogen and phosphate," International Journal of Scientific and Technology Research, vol. 8, no. 8, pp. 1338-1341, 2019.

[16] K. Velmourougane and R. Prasanna, "Modulating rhizosphere colonisation, plant 
growth, soil nutrient availability and plant defense enzyme activity through Trichoderma viride - Azotobacter chroococcum biofilm inoculation in chickpea," Plant Soil, 2017.

[17] K. U. Hasan, "Effect Of The Biofertilizer ( Azotobacter Chroococcum \& Trichoderma Harzianum ) And Levels Of Phosphate Rock On Growth And Yield Of Wheat ( Triticum Aestivum L . )," vol. 19, no. 2, pp. 4264-4268, 2019.

[18] A. Aminah, A. Abdullah, N. Nuraeni, M. S. Palad, and I. Rosada, "Effectiveness of Water Management towards Soil Moisture Preservation on Soybeans," International Journal of
Agronomy, vol. 2020, 2020, DOI: https://doi.org/10.1155/2020/8653472.

[19] G. E. Harman, "Trichoderma - not just for biocontrol anymore," Phytoparasitica, vol. 39, no. 2, pp. 103-108, 2011, DOI: https://doi.org/10.1007/s12600-011-0151-y.

[20] M. Benlloch and M. Benlloch-González, "Coregulation of water and $\mathrm{K}+$ transport in sunflower plants during water stress recovery," Journal of Plant Physiology, vol. 196-197, pp. 14-19, 2016,

DOI: https://doi.org/10.1016/j.jplph.2016.03.001 